\title{
Research on Application of Game Teaching Method in Children's Art Education
}

\author{
Xiangbin Gao \\ Linyi University, Shandong 273400, China \\ gxb0715@126.com
}

\begin{abstract}
At present, with the improvement of living standards and the rapidly development of the level of social economy, people pay more and more attention to the importance of education on the growth stage of children. As the formative education of the early childhood education stage, the education quality and efficiency of kindergarten education will directly affect the intellectual development and psychological development of children; and the game teaching method conforms to the characteristics of children and the principles of children's cognitive development. Coupled with the particularity of the object of education, the game teaching method is more important. The game is an important part of art education and teaching methods, because of this, people should pay attention to the intervention of the game in the children's art education. The important role of the game in the children's art education should be given full play. By introducing the importance of the game teaching method in the art education of young children, this paper makes an in-depth analysis on the application skills of the game teaching method.
\end{abstract}

Keywords: children art education; game teaching method; application.

\section{Introduction}

"Guidelines for kindergarten education" has pointed out: "kindergarten should provide health and abundant life and environment for children to meet the needs of their development, making them have the experience that is beneficial to their physical and mental development in the happy childhood life [1]." Games can exercise the manipulative ability of children, and is also very favorable in the physical and the training of creative ability, therefore, the game teaching method has been widely used in children's education. Affected by the age of young children, their attention is difficult to focus. So, if the teaching is carried out without a variety of games, the advantages and role of early childhood education cannot be played. The game is accompanied by the whole process of the art education of children, and the relationship between art and game is isomorphic [2]. They are permeable and interoperable. Children's art education can be carried out in the form of games, and the external performance of the game can also be an art form.

On the one hand, the game is an important part of children's art education, because the game and art have the intrinsic essential connection. There are a lot of similarities between the external performance of the two [3]. The game is an important resource for art education, and a lot of the games are art. On the other hand, the game is an important way to develop children's art education, and art education is organized in the form of game. Children have a lot of opportunities to play and perform the different roles. Especially in the comprehensive art education, the art activities are organized in the form of games, which can integrate many different kinds of art. This kind of art activities enrich children's artistic experience, meanwhile, the children can feel different artistic elements, such as music, dance, drama, etc.. In addition, some casual design involved in the game-based scene can often be able to exercise the ability of young children to connect different art. In the game, the creativity and the ability of change are endless. In the games, kinds of ideas, inspiration will be very easy to emerge. Therefore, early childhood education must be carried out in accordance with the regulation of the children's physical and mental development, so as to ensure that children can grow up with healthy and happy. 


\section{The Significance of Game Activities in Children's Art Education}

Game is an important way to expand children's knowledge and improve their physical fitness. For preschool children, the game is an important way to obtain knowledge and experience of life. In the course of the game, children can harvest a lot of skills which cannot be taught, and they will have great improvement in cognitive ability, thinking ability, imagination and perception. Because the children need to play different roles in the game during the game, and use their brains to solve some basic problems, and this is the key to improve children's ability to observation ability, analytical ability and the processing ability. The capacity and processing capacity.

Game is the key to improve the comprehensive ability of children. At the first stage of education, teachers need to have a plan and purpose to guide the children to form good habits of living and behavior. The comprehensive and extensive education in childhood can lay the foundation for later growth. The implementation of the game teaching method requires a certain rules, because the children love the game, so that they will actively participate in them, and obey the rules of the game, which can slowly cultivate their discipline. In order to complete the game content, children need to move constantly and think positively. The games with low intensity is an important way to open up children's thinking, improve the learning ability and cultivate good study habits.

\section{Application of the Game in Children's Art Education}

\subsection{Combination of the game plot and the content of art education.}

The kinesthetic experience and emotional experience of children were mobilized at the same time. The typical example is "Curwen gestures" created by a British, Jone·Curwen [4]. "Curwen gestures" is actually a kind of body language, aims to help them better experience the spaciousness of the interval in the musical scale through mobilizing the kinesthetic experience of children. The position of the gesture in "Curwen gestures" includes seven basic tone and two changeable tone. The use of gestures has a relative height range. The position of the "do" roughly parallels the waist and abdomen parallel. The position of each sound level of "re, mi, fa, sol, la, si, do" sises in turn gradually. The position of the high pitch "do" is roughly over the head, and the change of the thumb and index finger is used to represent the corresponding changes in the sound level. Because the "Curwen gestures" mobilizes the kinesthetic experience of children, so as to facilitate the children's perception and experience changes in the sound level, which makes the abstract concept of the pitch have a certain image meaning. In fact, in addition to the use of "Curwen gestures", other body action language also can be used to help children to experience the spaciousness of the interval, to strengthen their inner auditory feelings and deepen their emotional experience.

\subsection{Appropriate design of the game}

Game mode can cultivate children's competition consciousness in the learning process of children. Children have a strong psychological. According to the characteristic of that, we can design the game competition which conforms to their learning, to attract their thinking to the game activities and let students learn knowledge imperceptibly in the competition [5]. What should be paid attention in the game competition is that teachers should fully consider all of the children and give full play to the guiding role in the process of the organization of the game, and let the design od the game is conducive to the improvement of students' comprehensive quality.

\subsection{Proper performance of game in art education}

Teachers should calculate the thinking action ability of students in many aspects, and active the thinking method of children. The game performance is an important component of game activities in education. The content of the knowledge should be deepened through some of the real scene in the class. The knowledge can be integrated to the vivid scenes of life through the performance. Let the children be a small star and let them learn knowledge in the performance of the game and put the knowledge into practice, so as to achieve the important task of education, which is developing their communicative competence and flexibility. 


\section{Notes of Teaching Game}

\subsection{Selection of the form of teaching games}

Many people think that being a kindergarten teacher is easy. In fact, a good kindergarten teacher is not easy. The process of children's game seems simple, in fact, there are a lot of skills. The choose of the appropriate teaching game is a key part. Teachers cannot arbitrarily choose the game, they should connect it with the teaching content, so that children can learn what they should grasp step by step. Teachers cannot only create a situation for fun or active atmosphere, but should pay attention to the proper combination of the creation of the game situation and children's art learning. For example, teachers can help children to better identify the different areas and different pitches through the creation of "note fairy" [6]. Specifically, in order to create an unusual atmosphere for children, teachers have made the colorized note headdress with red, yellow and blue before the musical activity. Each group has seven notes from "do" to "si", and a "home" is drawn for each group of with corresponding color, such as caves, trees etc. Then, the children are voluntarily divided into three groups under the guidance of the teacher. They put on the headdress with red, yellow and blue colors respectively and find the "home" whose the color is corresponding to the color of the headdress. The children should clear with the teacher's help that the red headdress represents the treble tone, yellow represents the alto tone, and the blue represents the bass voice. So, the children with different colors headdress became the "note fairy" in different areas. After the beginning of the activity, teachers has played a piece of song which children is familiar with by different voice register and emotions. It is brisk in the treble area, it is firm and the speed id intermediate in the alto area, and it is slightly slower and strong in the bass voice. The teacher asks the children to distinguish the level of register after hearing these different style of play, and come out from the "home", do something to express his feelings of body movements. So, in this process, teachers can let the children play "note fairy" with headdress and design different "home" for the "note fairy" in different voice register, making children be in the special atmosphere of the game imperceptibly, so as to arouse students' interest in music and musical knowledge, and make the learning becomes vivid and interesting. The combination of the game and teaching could have great effectiveness.

\subsection{Time control of the teaching games}

The children's attention has a short time. The attention of children in primary class is about three minutes, the children in middle class is about three to eight minutes, and the attention of children in the top classes of children can be improved to ten minutes. In the game teaching, the teacher should control the time, and complete the teaching game in the children's most concentrated attention, so that teaching achievement can be extremely achieved.

\subsection{Difficulty control of teaching game}

The choose of game is very important, which must comply with the children's interest, and it cannot be too recondite and too rigid. So, the children constantly find new situations in the course of the game, and can start to think and solve new problems, so that children get the achievement of solving the problem, which can constantly stimulate children to seek knowledge interest.

\section{Conclusion}

The game teaching method has a positive significance to the development of preschool children's physical and mental development. The games inextricably link with children, art, and children's art education. In the teaching activities, the game teaching method should be fully used, which not only improves the teaching effect of teachers, but also helps children to get full development of physical and mental. Therefore, in the children's art education, we should pay attention to the significance of game for children's art education, and give full play to the role of the game in the children's art education, so as to promote the development of children's art education. 


\section{References}

[1] Hainey, T., Connolly, T. M., Boyle, E. A., Wilson, A., \& Razak, A.. A systematic literature review of games-based learning empirical evidence in primary education [J]. Computers \& Education, 2016, 102, 202-223.

[2] Alıncak F. Evaluation of opinions of primary school teachers on the method of education with game[J]. European Journal of Physical Education and Sport Science, 2016.

[3] Baladehi A S, Shirazi A. Study of the Appropriate and Inappropriate Methods of Visual Arts Education in the Primary Schools According to the Types of Multiple Intelligences[J]. Journal of History Culture and Art Research, 2017, 5(4): 501-513.

[4] Zeng, H., Liu, A. Q., Zhang, Y., Tao, H., \& Dong, Q. Q. Application of Teaching Games for Understanding (TGfU) in Preschool Children Basketball Education [J]. Research Quarterly for Exercise and Sport, 2016, 87(S1), S76.

[5] Balakrishnan, M., Rengasamy, S., \& Aman, M. S. Teaching game for understanding in physical education [J]. A theoretical framework and implication. Atikan, 2016,1(2).

[6] Baranowski, T., Blumberg, F., Buday, R., DeSmet, A., Fiellin, L. E., Green, C. S., ... \& Morrill, B. A.. Games for health for children-Current status and needed research [J]. Games for health journal, 2016, 5(1), 1-12. 